\title{
THE ROMANTICISM OF ELIZABETH BARRETT'S JUVENILe Poetics
}

\author{
Rachael Isom \\ Assistant Professor, Arkansas State University
}

IN A LETTER of 1828, twenty-two-year-old Elizabeth Barrett reflected on the famous Romantic poet George Gordon, Lord Byron: “he was a real poet!" He could "throw himself, in a transport of enthusiasm, on the earth before a cross, \& kiss the feet of the Crucified. You see_- the knowledge was not there_-but the feeling was there!" (BC 2:139, emphasis original). In her admiration, Barrett frames Byron not only as a man of feeling, but also as a related figure that was popularised during the Romantic period: an enthusiast. Like many of the prophets and poets who were labeled "enthusiasts" at the time, Byron's overwhelming fervour appears in his being transported through violent emotion, even ecstasy. ${ }^{2}$ Despite his physical body's being flung "on the earth," Byron's spirit is exalted heavenward by "the feeling" that, for Barrett, surpasses the religious knowledge one might have expected would inspire such prostration; moreover, this letter to Hugh Stuart Boyd claims that enthusiasm is part of what makes Byron "a real poet." It makes sense that Barrett, at this time a nascent poet herself, would appropriate the language of strong feeling that marked the literature of her childhood, and that she would cast herself as an enthusiast in the tradition of Byron. ${ }^{3}$ In her youth especially, Barrett praised the affective qualities that aligned Byron and other male Romantics with religious zeal, even in the absence of religiosity itself. She recognised from a young age how thoroughly the language of prophecy had infiltrated Romantic poetics, and how its tropes and theories inflected the gendered conventions of literary professionalism.

The primary way this infiltration occurred was through the figuring of the poet as an enthusiastic genius. Born of historical intersections between religious prophecy and secular improvisation, enthusiasm was, by the time Barrett was born, a fluid concept that both empowered and compromised writers. Appeals to divine inspiration could authorise a poet's strains, but links to Dissenting theologies and fanatical zeal had serious social consequences during the eighteenth century and well into the nineteenth. Even in its more secular forms, enthusiasm represented a tricky

(cc) Isom. This article is distributed under a Creative Commons Attribution-NonCommercialNoDerivatives 4.0 International Licence (creativecommons.org/licenses/by-nc-nd/4.0/).

Journal of Juvenilia Studies 2.I (2019), pp. 28-45. DOI: 10.29173/jjs32 


\section{Rachael Isom | Elizabeth Barrett's Juvenile Poetics}

negotiation of strong feeling, especially for women who had to contend with stereotypes of hyper-emotionality and hysteria. ${ }^{4}$ This history of "enthusiast" identity helped male Romantics articulate a theory of poetic fervour-we might think, for instance, of William Wordsworth's famous dictum, "all good poetry is the spontaneous overflow of powerful feeling" (Preface 756). In claiming as masculine this particular brand of enthusiasm, however, poets and literati of the age often alienated women writers whose poetics fell along similar lines of inspiration and strong feeling. ${ }^{5}$ The enthusiast figure in literature thus exposed the seams in Britain's cultural assumptions about gender, belief, and vocational authorship. In doing so, it fundamentally shaped how the young Elizabeth Barrett's predecessors and contemporaries thought about themselves as poets and professionals. As I hope to show, enthusiasm influenced Barrett's self-conceptualization as well.

As a child, Elizabeth Barrett enjoyed the privileges of wealth, parental support, and an exceptional education. She spent her youth at Hope End Estate, an "idyllic home" that, as Simon Avery explains, was financed by sugar plantations owned by both sides of Barrett's family. Her later poetry condemns slavery and wrestles with its connection to her own childhood advantages ("Constructing" 25, 38-40). While at Hope End, Barrett's literary pursuits benefited from the encouragement of doting parents: Barrett's mother fair-copied many of her "juvenile productions," and her father began calling her the "poet laureate of Hope End" (Mermin 10, 14, 16). Her extensive reading, along with her study of Greek and Latin, provided training atypical for even the most privileged of nineteenth-century girls (Avery, Lives xxvi; Avery and Stott 2; Forster 19; Mermin 17-20). Barrett was also unusual in that she spent much of her adolescence-from the age of thirteen-grappling with physical illness that isolated her from family, friends, and the outside world (Forster 20-25). Thus, with her remarkable intellectual training and early invalidism, Elizabeth Barrett grew up unusually situated to reflect at length on her own literary character and to imagine her compositions in relation to those she read from antiquity to her own day. Her early writings praise and emulate Romantic strong feeling, but they also address the conflated-and sometimes conflicted-enthusiasms at the root of this tradition.

My aim here is to trace the language and figures of enthusiasm across Barrett's juvenilia, in order to establish her investment in the concept during those formative years and to show the influence of Romantic-era poetics on her self-representation as a child-poet. I begin with two childhood autobiographies: "My Own Character" (1818) and "Glimpses into My Own Life and Literary Character" (1820, hereafter "Glimpses"). The first was written when Barrett was twelve and copied by her mother, Mary Moulton-Barrett (ABL Ms. D1326); it is generally considered an early draft of the longer and better-known "Glimpses," begun when Barrett was fourteen ("Two Autobiographical Essays" 119; Avery, Lives 1). Significantly, Barrett wrote this second essay in the wake of her abrupt exclusion from Greek studies, precipitated by her brother Edward's entering Charterhouse School (Mermin 19-20, Forster 19). Produced during a period of considerable change in Barrett's childhood, these two essays reflect on the literary world in which she was growing up as well as the extent to which she understood that world's parameters as a means for articulating her own abilities, flaws, and ideals. In "My Own Character," Barrett's youthful enthusiasm 


\section{JJS July 2019}

clashes with her perceived need for-and difficulty with—self-reflection. "Glimpses" further develops what Charles LaPorte calls Barrett's "celestial aesthetic," a philosophy that holds Romantic poetics in "interdependence" with "evangelical emotion" (Victorian Poets 48, 45). In this article, I reframe that fraught interdependence via the discourse of enthusiasm Barrett invokes in these memoirs. Reading the young poet as a self-conscious Romantic enthusiast illuminates her productive conflation of religious and literary fervour at this stage.

Analysis of these two essays helps us consider how Barrett's first major volume of poetry, An Essay on Mind, with Other Poems (1826, hereafter Essay), follows the principles of her juvenile autobiographies to their logical conclusion: that enthusiasm is necessary for writing poetry and for establishing poetic identity. Essay was published anonymously shortly after Barrett's twentieth birthday, but, as Sandra Donaldson notes, much of the title poem was extant in draft form by the time Barrett was eighteen years old (Works 4:82; BC 2:35). Thus, although printed for public consumption in 1826, Essay can be read as another teenage meditation on poetic identity; furthermore, Essay never appeared under Barrett's name during her lifetime, suggesting that she later viewed it, like her childhood memoirs, as a reflective exercise rather than part of her more formal, professional oeuvre (Works 4:75, 83). Composed during what we now consider the Romantic period, "My Own Character," "Glimpses," and An Essay on Mind largely reflect Romanticism's aesthetic values and its anxiety about compromising associations with religious enthusiasm. This body of juvenilia thus situates Barrett as a transitional poet who understood — and modifiedRomantic-era conceptions of enthusiast identity by articulating her own artistic proclivities and professional trajectories. As a child, Barrett saw controlled separation of religious and secular enthusiasms as the only path to legitimation, but these texts host her adolescent rethinking of the relationships between poetry and prophecy, belief and vocation. As such, they are crucial to our understanding of Barrett's juvenile poetics, her later career, and to the new female poet she defined for the Victorian age.

As early as age twelve, Barrett incorporated the vocabulary and tropes of enthusiasm into her private reflections, but she already expressed unease at the social implications of enthusiasm's power. "My Own Character" notes Barrett's early tendency to "seek truth with an ardent eye" and "a sincere heart" and to approach all things with a "very passionate" disposition (347, 348). Such linkages between enthusiasm and "ardent" feelings, especially as figured in women's eyes, are well documented in scholarship (see Juster 18, 127-28); in Barrett's summary, these indicators of passion show her willingness to admit (if not necessarily boast about) the strong feeling she saw in the Romantic poets of her youth. Barrett's acknowledgement of these characteristics arrives in "My Own Character" through the filter of religious introspection. As some editors note, what appear as Lockean musings in Barrett's autobiographical essays can be more accurately described as "spiritual self-examination" in the eighteenth-century Evangelical mode ("Two Autobiographical Essays" 119n; Avery, Lives xxv-xxvi). ${ }^{6}$ Accordingly, Barrett discusses self-reflection's difficulty and her avoidance of it: "I have never, even in imagination looked into my own heart," she confesses, before opining, "The investigation of oneself is an anxious employment" ("My Own Character" 347). 


\section{Rachael Isom | Elizabeth Barrett's Juvenile Poetics}

Perhaps Barrett's reluctance to imaginatively self-evaluate reflects the same faults that deter many Romantic-era enthusiast figures: confidence in her own inspiration and feelings as well as a desire for notoriety through their expression. In this first memoir, then, Barrett seems more keen to value imagination for its own sake than to appreciate its capacity for self-critique and self-control.

Tensions between Barrett's seemingly uncontrollable emotion and her constant efforts to control it drive her second, much longer autobiographical reflection, "Glimpses into My Own Life and Literary Character." Given that she later deletes "enthusiasm" from her professional vocabulary, ${ }^{7}$ Barrett appears remarkably comfortable using it to describe her youthful poetic disposition in this text: forms of the word appear no less than eleven times in "Glimpses," almost always selfreferentially. According to her own account, Barrett's enthusiastic character manifested at age three when she became "renowned amongst the servants for self love and excessive passion" ("Glimpses" 349). ${ }^{8}$ It seems unlikely that, at three years old, Barrett demonstrated passion in the vein of the heroines, prophetesses, and poetesses who proliferated during the Romantic age; however, the passage of time and the eventual protuberance of sentimental qualities probably led Barrett to begin her memoir of literary character with the image of a headstrong child replete with what she-at fourteen-viewed as the makings of poetic greatness à la Byron and company. By characterizing her youthful passion as "excessive," she here figures it as an overpowering trait to be monitored and regulated as she grows.

Having once established herself as an enthusiast from the cradle, Barrett freely uses the term and its cognates to describe her adolescent personality throughout the rest of "Glimpses." The first instance coincides with her introductions to Greek history and to poetry, where she "first found real delight" ("Glimpses" 350). The passage reveals the eight-year-old subject's need for stimulation ("something dazling [sic] to strike my mind"), but it also shows the fourteen-year-old author's compulsion to revive the strong feeling of that initiation experience: "Every stanza excited my ardent admiration nor can I now remember the delight which I felt on perusing those pages without enthusiasm" (350). The layering shows enthusiasm's sustained influence on Barrett's responses to poetry and to her own meditations on poetic experience. This persistent enthusiastic character appears in recurring vocabulary and repeated images across Barrett's early writings. For example, "Glimpses" revives "My Own Character"s use of "ardent," which in the above quotation characterises Barrett's admiration of poetry. It later describes ten-year-old Barrett, who "felt the most ardent desire" to learn ancient languages and "sighed for so long . . \& so ardently!" over the literary fame she then perceived as inaccessible ("Glimpses" 350, 351). "Ardent" and "fervent" commonly describe enthusiastic figures in literature of the eighteenth and early nineteenth centuries, and these words' usage persists at the time of this essay's composition. With such diction, then, Barrett evokes those overlapping archetypes: the prophetess, the improvising poets, and the man of feeling.

Barrett's second memoir, like her first, appropriates the physical attributes of enthusiasts as recognised during the Romantic period; fires and fevers make several appearances in "Glimpses of My Life and Literary Character." For example, Barrett 


\section{JJS July 2019}

mentions that she felt "the fever of a heated imagination" at age eleven, and at twelve her "imagination took fire" at "a sudden flood of light" she interpreted as a sign of God's forgiveness ("Glimpses” 351, 352). Interestingly, while Romanticists readily invoke incidents like William Blake's vision of "a tree filled with angels" as evidence of juvenile inspiration (Gilchrist I:7), this visionary episode in Barrett's childhoodone of two that occurred when she was around twelve years old (see "A Vision An Allegory")— has received little or no attention, perhaps due to gender- or periodbased assumptions. But here, as with male Romantic poets like Blake, the event bears immediate significance for Barrett's understanding of poetry as inspired and inspiring. Barrett links the "flood of light" to her imagination, and her imagination to enthusiastic warmth. In the very next sentence, she recalls how the works of William Shakespeare, John Milton, and Alexander Pope metaphorically elevate her blood's temperature: "I have often felt my soul kindled with the might of such sublime genius \& glow with the enthusiasm of admiration!!" ("Glimpses" 352). ' Her soul kindles and glows like a flame, its intensity reinforced by the double exclamation at the sentence's end. The fire metaphor pertains to both religious and literary enthusiasms, and reappears when Barrett writes that her "admiration of literature," early described as enthusiastic, "can never be ... extinguished but with life" ("Glimpses" 353). At this juncture of her life as a reader and writer of verse, Elizabeth Barrett not only lived in what we now call the Romantic period; she also understood lived experience through its formulation of poetic genius as a volatile, fiery, innate force that commands emotional desire, inspiration, and admiration.

At this stage of her development, then, Barrett saw poetic feeling as necessarily bound up with spiritual fervour; moreover, as uses of "enthusiasm" in this text show, she had not yet separated poetry from prayer or poet from prophet. Moving quickly among literature, philosophy, and religion, she "blurred conventional distinctions between forms of inspiration" and conflated modes of spiritual and secularised elevation under the umbrella of enthusiasm (LaPorte, Victorian Poets 25). "Metaphysics were my highest delights," she avers in "Glimpses," invoking the "enthusiastic sensation" of "high delight" in standard eighteenth-century aesthetic theory but also calling to mind religious ideas of God's service as "delight" as expressed in the Psalms, in the Book of Common Prayer, and in Congregationalist hymnody ("Glimpses" 351, Gilpin 49-50)..$^{10}$ Accordingly, Barrett's memoir aligns her responses to natural and supernatural phenomena: she tells us that at "the pure and wide expanse of Ocean" and the immense "majesty of God," her heart "throbbed almost wildly with a strange and undefined feeling" ("Glimpses" 354). Lockean philosophy similarly leaves her mind not only "edified but exalted" ("Glimpses" 351). At fourteen, Barrett conceives of faith, philosophy, and literature as products of imagination that she can combine in new ways. With her heart and mind "in commotion" from "internal reflections \& internal passions" ("Glimpses" 352, cf. 353), inspiration and imagination define her as an enthusiast in conventional Romantic terms.

Perhaps most telling is the extent to which the young Elizabeth Barrett, even more than many of her Romantic predecessors and contemporaries, conceived of herself as an enthusiast according to Romantic-era theological definitions of the term. At age twelve, she found herself 


\section{Rachael Isom | Elizabeth Barrett's Juvenile Poetics}

in great danger of becoming the founder of a religion of my own[.] I revolted at the idea of an established religion-my faith was sincere but my religion was founded solely on the imagination. It was not the deep persuasion of a mild Christian but the wild visions of an enthusiast. ("Glimpses” 351; cf. Avery, "Constructing” 37)

Barrett's disdain for institutionalised religion and her capacity to flout it by creating her own belief system link her strongly with the Romantic-era Dissenters who were commonly labeled "enthusiasts." Barrett recalls nearly joining these maligned religionists by establishing a new faith on "imagination" alone. Indeed, "enthusiastic faith" leads her away from the "pure \& simple" rites of Anglicanism's holy book toward original prayers "composed extempore and full of figurations and florid apostrophes" to God ("Glimpses" 351). She infuses her religion with poetry in ways she recognises as dangerously self-authorizing, especially for women. Male Romantics like Blake could admit their childhood ecstasies - even if readers thought them strange, they regarded them as marks of poetic vision. But Barrett, like many of the Romantic women whose careers were ending as hers began, understood that "the wild visions of an enthusiast" did no favours to the young woman seeking poetic fame in nineteenth-century Britain ("Glimpses" 351). Since Barrett is often billed as a secular (or at least noncommittally religious) poet in a religious age, her early fervour may come as a surprise; however, Barrett's theology influenced her poetry far more than many modern scholars acknowledge (see LaPorte, Victorian Poets 23-25; Avery, "Constructing" 36-38; Dieleman 23-29). To judge her "naturally independent" mind apart from its early formation in religious dissent is to give an incomplete account of Barrett as poet ("Glimpses" 355). These roots of enthusiasm inaugurate and continue to inflect the growth of her poet's mind.

Along with restoring the narrative of Elizabeth Barrett the self-described enthusiast, we should also acknowledge that she, like her Romantic predecessors, was intensely aware of enthusiasm's social consequences for authors and, as she matured, increasingly worked to mitigate those consequences in her public career. In "Glimpses," much more than in "My Own Character," Barrett seems preoccupied with controlling the uncontrollable in her early character. Her "mind has and ever will be a turmoil of conflicting passions"; her feelings are "acute in the extreme," and, she laments, "the strength of my imagination" is "often too powerful for my controul" ("Glimpses" 353, 352). Though she hopes "in time at least [to] keep them under some controul," Barrett nevertheless does not view enthusiasm as dangerous enough to squelch it immediately or entirely ("Glimpses" 352, emphasis added). Instead, she recognises that to do so would effectively mean nullifying her gift. In this way, "Glimpses" reiterates the Lockeanism of "My Own Character" and echoes Romantic theories of the poet-prophet. In 1818 Barrett had quibbled with Locke's denial of innate principles in human beings but ultimately conceded that certain principles only appear innate because "the faculties of some men are more sensible to impressions than those of others" ("Two Autobiographical Essays" 120-21). ${ }^{11}$ In other words, the poet's power rests in her naturally heightened sensibility. Wordsworth had argued 


\section{JJS July 2019}

along these lines in "Ode: Intimations of Immortality from Recollections of Early Childhood" (1807) and was at this time revising a similar claim in The Prelude or, The Growth of a Poet's Mind (1805/1850). In her early poetic theory, Barrett's sense that "energy or perhaps impetuosity ... allows" her "not to be tranquil" strikes a quintessentially Romantic balance between the emotion she celebrates and the tranquility she disdains for "precluding in great measure the intellectual faculties of the human mind!" ("Glimpses" 353). Her juvenilia partake liberally of the Wordsworthian doctrine of powerful feeling, but eventually Barrett found an affinity with another of his famous dicta: that "recollection in tranquility" is essential to the poetic process (Wordsworth, Preface 756; cf. K. Blake 389-98).

Imagination, sentiment, and enthusiasm: young Barrett considered it her "study to subdue" these "attributes" as part of her poetic education ("Glimpses" 352). By framing this process as "study," she characterises self-control, unlike the emotions it seeks to tame, as a learned quality. In other words, "Glimpses" delineates how a young Barrett developed a critical eye to counteract her throbbing heart. Of her efforts at twelve or thirteen, she writes, "I now read to gain idea's [sic] not to indulge my fancy" (352). These efforts could only go so far, however, and she finds herself at fourteen "still as proud as willful as impatient of controul as impetuous but thanks be to God it is restrained" (353). As with the enthusiasts before her, self-control does not change her character; it merely shapes it in more socially acceptable ways. At this juncture she constructs a stoic alter ego for public consumption:

I have acquired a command of my self which has become so habitual that my disposition appears to my friends to have undergone a revolution-But to myself it is well known that the same violent inclinations are in my inmost heart and that altho' habitual restraint has become almost a part of myself yet were I once to loose the rigid rein I might again be hurled with Phaeton far from every thing human ... every thing reasonable! (“Glimpses” 353)

Barrett's self-control, like that of her forerunners, is "acquired" through "habitual restraint." We may note that Barrett uses "habitual" twice in this short passage, implying that presenting as a reformed enthusiast requires diligent monitoring and exertion-a "rigid rein" to control a wild horse. A few pages later, she reiterates the sentiment and repeats much of the language: "I have so habituated myself to this sort of continued restraint, that I often appear to my dearest friends to lack common feeling!" (“Glimpses” 354). Fourteen-year-old Barrett devotes considerable time and energy to self-control and personal improvement because she knows they will affect public opinion and, eventually, the reception of her work. Perhaps her early sense that "nothing is so odious ... as a damsel famed in story for a superabundance of sensibility" is what keeps her "carefully restrained!" ("Glimpses" 354). In any case, Barrett's cataloguing of successes and failures in restraint attends to gendered double standards of emotionality and alludes to other female enthusiasts' (often unsuccessful) strategies for dealing with them. 


\section{Rachael Isom | Elizabeth Barrett's Juvenile Poetics}

Shifts in Barrett's religious affinities between 1818 and 1820, and again by the mid-1840s, show the effects of this early restraint on her enthusiastic identity. In "Glimpses," she recalls how "religious enthusiasm had subsided" by the age of thirteen-between her two memoirs - and how she had begun "to advocate for the cause of the church of England!” (352). ${ }^{12}$ But Barrett's newfound institutional religion does not preclude imagination. She admits to still being "borne away from all reason" by its "fatal power" ("Glimpses" 352). In attempting to divide spiritual from secular powers, Barrett draws a nominal line, then, between the regrettable naïveté of her youth and the strong feeling of a mature reader. At fourteen, she describes her character thus:

My religion is I fear not so ardent but perhaps more reasonable than formerly and yet I must ever regret those enthusiastic visions of what may be called fanaticism which exalted my soul on the wings of fancy to the contemplation of the Deity-My admiration of literature, especially of poetical literature, can never be subdued nor can it be extinguished but with life. ("Glimpses" 353)

Barrett laments draining the "ardent" feeling essential to her childhood spirituality; that is, until she links it with controversial religious feeling. She now considers "enthusiastic visions" fanatical rather than freeing, and the exaltation of her soul relies on "fancy," which famously played second fiddle to "imagination" in Romantic poetics. ${ }^{13}$ Diminishing her religious enthusiasm in these ways helps Barrett foreground its more acceptable cousin: zeal for literature. Later texts like Aurora Leigh (1856) show greater capacity for recognizing, chastening, and qualifying enthusiasm. In her adolescence, however, Barrett has not yet learned to restore that enthusiasm in a productive manner. Instead, in "Glimpses," she habituates herself to creating a clear division between her formerly conflated religious and poetic zeal. In doing so, she finds a temporary strategy for managing the enthusiasm that she saw as endangering her literary goals and reputation. She extricates and subdues the part known to compromise professionalism.

Barrett's compartmentalizing approach in "Glimpses" does not necessarily mean that she opposed religiosity to intellectualism or that she continued to view enthusiasm only in terms of a spiritual versus secular dichotomy. Barrett occasionally frames her adolescent fervour in political terms as well. For example, "Glimpses" describes the fourteen-year-old Barrett as something of a political firebrand: "I am capable of patriotism enthusiastic \& sincere. At this period when the base \& servile aristocracy of my beloved country overwhelm with insults our magnanimous and unfortunate Queen I cannot restrain my indignation I cannot controul my enthusiasm" (353). Here Barrett responds angrily to the treatment of Caroline of Brunswick, whom George IV attempted to divorce when he became king in $1820 .{ }^{14}$ Interestingly, Barrett's youthful patriotic fervour-like her poetic and religious enthusiasms - escapes her control. The run-on construction and near repetition of "I cannot restrain I cannot controul" makes even more palpable her intensifying anger about current events. A similar disquisition on politics appears in a brief essay Barrett 


\section{JJS July 2019}

wrote the next year. "My Character and Bro's Compared" (1821), another juvenile work that remained unpublished during her lifetime, largely constructs Barrett's identity in relation to that of her brother Edward. "We are each fiery in politics," she writes, "but Bro's patriotism is dictated by reason, justice \& a proper portion of moderation, mine is more ardent \& more enthusiastic!" (357). The fifteen-year-old Barrett here identifies two versions of political engagement: one "dictated" by an outside system of masculine reason and one that eludes its moderating effects. The word "ardent" also returns here, suggesting that Barrett viewed her enthusiastic political bent in the same vein as her fervent approach to poetry and religious belief. As in her earlier memoirs, enthusiasm remains a defining feature of her childhood character.

We continue to see in Barrett's later career-one that boasts religious and nonreligious verse alike - that enthusiasm was a fluid concept, and that faith-based and secularised expressions of enthusiasms could be housed within the same poet. Barrett's theological ecumenism informs these views as she works to disentangle various enthusiasms that had intersected somewhat messily in her early writing. For example, in October 1831, when Barrett was twenty-five years old, she debated with one Mr. Curzon "about the compatibility $<<$ or $>>$ incompatibility of intellectual \& religious <<pleasures $>>$." "Of course," she quips, "Boyd \& I took the right side of the question," presumably (based on other exchanges she reports having had with Boyd) that of "compatibility" Boyd (Diary 163). By the 1830s, Barrett had become less interested in wrenching spiritual fervour from literary admiration, which suggests that her early divisive tendencies arose from concerns about how she and her work would be perceived. Barrett had been stuck in a double bind: she could not countenance a melded poet figure without rejecting melded enthusiasm as her driving characteristic. By this point, however, she exhibits and values enthusiastic qualities still, but they have now been carefully sorted and reassembled to avoid compromising associations with her predecessors.

Additional diary entries from the early 1830s reveal Barrett's partitioning of literary zeal from religious fervour in her writing about prophecy. These private writings show that she viewed herself as a prophet; however, like many Romantic poets, Barrett approaches prophecy from Greek rather than Hebrew models. ${ }^{15}$ In September 1831, for instance, she uses two figures of speech: "prophesying ill" and "prophet of ill," both reflexive and, more significantly, both in Greek (Diary 112, 137). ${ }^{16}$ These interpolations could be explained as language practice since, after all, Barrett was studying Greek while translating Prometheus Bound. But she never includes whole Greek sentences in this diary, nor does she translate other religious phrases, despite their frequency. She reserves Greek for prophecy and, in one particular instance, for poetry. On 24 September 1831, Barrett praises Percy Bysshe Shelley's elegy Adonais as "perfectly exquisite" before calling Shelley himself "one of [those sitting near the gods], without any doubt" (Diary 138). ${ }^{17}$ The bracketed text has been translated from Barrett's Greek. She employs it to register proximity to deity, as well as the special knowledge that comes of it. By connecting that knowledge to a specific poem, Barrett yokes poetry and prophecy together and to Greek traditions of both. Shelley would likely have appreciated this assessment, since his own idea of poets as 


\section{Rachael Isom | Elizabeth Barrett's Juvenile Poetics}

prophets relied heavily on the Greek vates figure. ${ }^{18}$ The linguistic details of Barrett's personal reflections at this juncture reveal a similar belief that the kind of prophet matters when it comes to legitimizing oneself as a poet, and especially as a poet for the coming age.

It is near the end of the Romantic period, however, that Barrett's early volume An Essay on Mind, with Other Poems (1826) launches her adult publishing career and helps mediate the private theories of her adolescent memoirs in advance of her 18311832 diary. As Dorothy Mermin observes, An Essay on Mind treats the "thoroughly Romantic subject" of genius (40); furthermore, at this crucial juncture in Barrett's career, the volume distills and modulates her early principles to form her most explicit assertion yet of poetry's vitally enthusiastic nature. In the preface she declares, "Poetry is the enthusiasm of the understanding" (78). This definition is striking, all the more so because Barrett later avoided forms of the word "enthusiasm" in her professional writing. In 1826, though, she affirms the centrality of enthusiasm for Romantic poetics; moreover, she extends that theory by asserting that poetry is enthusiasm. Here, Barrett seems to have taken Shelley's view of poetry as a particular brand of enthusiasm based in understanding, or intellectual reason, not in physicalised religious fervour. The titular poem clarifies this distinction: "Poesy's whole essence, when defined, / Is elevation of the reasoning mind" (Essay 944-45; cf. Avery, "Audacious Beginnings" 58). Taken together, these definitions of poetry identify enthusiasm as necessary to its creation and to its primary function of enhancing the power of reason through feeling. Barrett aligns pure reason with Philosophy but argues that it "cannot plainly see" without the aid of "Poetic rapture, to her dazzled sight" (Essay 909-910, emphasis original). Furthermore, Poetry educates Reason: "inward sense from Fancy's page is taught, / And moral feeling ministers to Thought" through the tools of verse: "metaphor," "eloquent" diction, and, most aptly, "Poetic fire" (Essay 94647, 956-58). Her earlier cautions about "fancy" and "feeling"-even about enthusiastic fire-have matured into an argument for how these impulses play significant roles in the growth of the poet's mind. Thus, while Barrett claims that only one sort of enthusiasm will work for the poet, she concedes that the poet cannot work at all without enthusiasm's mysterious power.

According to Barrett, enthusiasm's power is at the heart of the poetic process's magical extraction of beauty and intellect from physical sensation. The task, carried out by the poet's soul and mind, looks like this:

When pleasing shapes and colours blend, the soul

Abstracts th' idea of beauty from the whole,

Deducting thus, by Mind's enchanting spell,

The intellectual from the sensible. (Essay 783-86, italics original)

Barrett imagines the soul as the main actor in poetic composition, while Mind provides the "spell" that draws reason from sense. ${ }^{19}$ The roles seem reversed; however, the Mind as Barrett conceives of it "clings / Less to the forms than essences of things," thus enabling the poet to abstract ideal beauty from its more muddled earthly form (Essay 773-74). This principle recalls Barrett's youthful effort to "read 


\section{JJS July 2019}

to gain idea's" without becoming distracted by the impulses of Fancy ("Glimpses" 352). But Book II of Essay suggests that in 1826 Barrett was still caught in a paradox: she claims here that poets can deduct "The intellectual from the sensible" but only through enchanted means. This formulation reflects the anxieties about enthusiasm present in Barrett's earlier essays. Intellectual enthusiasm had there become inextricably tangled with more physicalised, prophetic understandings of the term, with the result that when Barrett commits to a Romantic idea of poetry as inherently and beneficially enthusiastic, she must also admit Romantic feeling into her formula for poetic insight. In other words, the abstraction of essence from form could never be performed cleanly, even with the aid of magic. These early struggles may help explain why Barrett omitted the term "enthusiasm" from later work: she came to realise that even lofty enthusiasm often takes the forms of sense, and that increasingly vocational notions of enthusiasm as applied reason required poets to work through feeling to teach, delight, and elevate.

The word "enthusiasm" features prominently in Barrett's preface to An Essay on Mind, as we have seen, but from the poem itself the term is conspicuously absent (as it is from later works). Nevertheless, the concept's manifestations as inspiration, strong emotion, and poetic effusion fill Barrett's philosophy via an alternative catchword: "genius." In An Essay on Mind, Genius retains three key characteristics of enthusiasm: heightened energy that appears in metaphors of fire and sunlight, variance in receptivity to that energy, and the calling of enthusiastic minds to reflect it from divinity to humankind. As Barrett writes in Book I:

Thus, in uncertain radiance, Genius glows, And fitful gleams on various mind bestows:

While Mind, exulting in th' admitted day,

On various themes, reflects its kindling ray.

Unequal forms receive an equal light ... (Essay 86-91)

With the "kindling ray" of Genius's sun, Barrett invokes enthusiasm's ubiquitous fire and light imagery; by making that ray equally distributed but unequally received, she implies that the poet's mind more readily perceives and reflects Genius's power. As a "mystic essence," Genius can "define / The point, where human mingles with divine" (Essay 127, 202-3). A metaphor we find just a few lines earlier illustrates this point: Barrett invites the poem's auditor to "Mark Byron, the Mont Blanc of intellect, / 'Twixt earth and heav'n exalt his brow sublime, / O'erlook the nations, and shake hands with Time!" (Essay 70-71). ${ }^{20}$ This metaphor clarifies Barrett's Romantic conception of genius as the quality that elevates poets to a glorified position between human and divine. As Avery puts it, Barrett views Byron as both "spiritual and humanitarian leader" ("Audacious Beginnings" 59). Fifteen years later, she saw Shelley in a similar though less positive light: "high, \& yet too low," an "elemental poet, who froze in cold glory between Heaven \& earth, neither dealing with the man's heart, beneath, nor aspiring to communion with the supernal Humanity" (BC 5:60, qtd. in Stabler 235). For Barrett, genius's mingling power can also isolate and chill individual poets, even those who reflect its rays most brightly. The in-betweenness of 


\section{Rachael Isom | Elizabeth Barrett's Juvenile Poetics}

the poet's vocation can foster connections to humanity and divinity, but more often it disconnects the poet from her readers and the earthly realm they inhabit.

As Barrett's Essay reveals, however, the human mind is not, in her view, the only variable in the mysterious equation of poetic enthusiasm, or in determining the outcome for poets who attain genius status. Barrett emphasises the uncertainty and fitfulness of Genius throughout Book I, both in the abstract and with reference to particular poets. For instance, in lines 435-37, Barrett mirrors Genius's inconsistency through indecisive drafting. The published version reads: "Genius! behold the limits of thy power! / Thou fir'st the soul - but, when life's dream is o'er, / Giv'st not the silent pulse one throb the more" (Essay 435-37). Here Barrett counters Genius's presumed omnipotence by emphasizing human mortality. The first attempt reads quite differently: "Hear Earth! how Genius falters in her trust - / She fires the soul, but cannot warm the dust" (ABL Ms. D0247). With the apostrophe directed to Earth, Barrett speaks about Genius much as she does earlier in Book I. More importantly, she theorises Genius's inconsistency as a faltering or lapse rather than an inherent limitation, and that faltering as a breach of "trust" in the relationship she holds with Earth and humanity. These lines have been crossed out and a slip of paper pasted over them, reading: "How boastful Genius falters in her power! / She fires the soul - but, when life's dream is o'er...” (ABL Ms. D0247). This second version, like the first, laments Genius's failure to vivify the body as she does the soul, but the imagery becomes less literal, less biblical. More cancellations yield the final version, which addresses Genius directly. Perhaps Barrett has reconsidered her blaming of Genius and instead reveals its "limits" while acknowledging its "power." These lines-and Barrett's hesitation in finalizing them-suggest that Genius breaks the promise of immortality to poet-enthusiasts, or even that it does not have the power to make that promise at all. In either case, the young Barrett suggests that Genius cannot sustain human ties in life or in death. Her reflections on Byron, on Shelley, and on herself demonstrate Barrett's concerns with the isolating effects of enthusiastic power on the poet who lays claim to it.

In addition to theorizing the complicated identity of the enthusiast-poet in society, Barrett's Essay on Mind also helped early readers situate her as a new poet in relation to that identity and to the Romantic standard-bearers she had invoked. In fact, around the same time that Barrett was reflecting on Byron's enthusiasm in her letter to Boyd, an unknown reader was considering Barrett in much the same light. A piece of unidentified correspondence, tentatively dated 1826, contains an encomiastic sonnet "To Miss Barrett, on reading her 'Essay on Mind"' (BC 2:231). The poem not only recognises Barrett as author of the anonymously published Essay ${ }^{21}$ but also links her explicitly with her hero, Lord Byron: "Thy Seraph muse wings her bright meteor flight / Above thy sex's far as Byron's harp / Sounds o'er his brother's, or Day outshines Night" (lines 9-11). The poet solidifies this link between Barrett and Byron by using the vocabulary and tropes of enthusiasm, following connections that Barrett was making herself. Her "words of fire" make her a "bright meteor" that blazes above the poetesses of her day; moreover, this flight inspires a near-religious devotion among readers who experience "transport wild"-just like Byron in Barrett's letter to Boyd-at reading her "lofty" verse (lines 3, 9, 4-5). ${ }^{22}$ Finally, and perhaps most 


\section{JJS July 2019}

importantly, this sonneteer views Barrett's enthusiast status as fundamentally linked with her youth. As "Poesy's young child," the poet suggests, Barrett can unleash the passionate character described in her juvenile autobiographies; however, like the young Barrett herself, this poet recognises that passion's attendant danger and implores the nine Muses and the god Pan to safeguard the newest member of their classical poetic tradition (lines 2,13-14). This poem suggests that, while Barrett was still contemplating how closely she should identify with the Romantic enthusiast identity, some readers had already linked her with it. And while society was often wary of enthusiasm, at least one of them considered it auspicious for a young poet beginning her professional career.

They were right. Over the next four decades, Elizabeth Barrett (later Browning) built a prolific career with poems ranging from ballad to sonnet to monologue to epic. She established herself as a pillar of Victorian verse and crafted the period's foremost theory of the woman writer as literary professional. Although Barrett's juvenilia did not yet crystallise the female poet as would that "most mature of [her] works," Aurora Leigh (Browning, Works 3:1), it did set the stage. Barrett's early essays and poems look inward to contemplate her own values as a writer, but they also looked to Romantic conceptions of prophetic and poetic fervour; moreover, Barrett used liberally the Romantic term that best embodied these conflated ideas: enthusiasm. These early texts flirted with the more Romantic model she saw in Byron, Wordsworth, and Shelley. During the 1810s and 1820s, Barrett studied enthusiast models from antiquity through her present, often struggling to reconcile the power and attendant danger of Romantic strong feeling. Her painstaking efforts to separate and then to reunify spiritual and secular notions of enthusiasm make her early poetic theory far more Romantic (and more religious) than typically recognised.

Studying Barrett's juvenile autobiographies provides crucial insight into her thinking on poetry, enthusiasm, human nature, and literary identity from the vantage points of twelve and fourteen; moreover, the retrospective qualities of "My Own Character" and "Glimpses" show a young woman eager to chronicle her own life as another example of Romantic genius. Even as she cast herself as an enthusiast in the mould of Byron, Barrett knew this model was changing, and she expressed candidly her concerns about controlling the poetic fervour at the source of her power. Thus, the writer who theorises enthusiastic poetics for a public readership in An Essay on Mind approaches that task from a place of self-conscious authorship that had been cultivated with great care over Barrett's teenage years and articulated with reference to important changes in religious and literary history. Although none of these texts joined Barrett's formal body of work during her lifetime, they reveal her deliberate, adaptive self-fashioning as a poet of one age who recognised the social demands of the next. As a juvenile poet, Barrett was eager to join the ranks of her favourite writers. As an author coming of age in a transitional moment, she entered the conversation about what poetry had been and would be. Barrett's youthful disquisitions on enthusiasm, feeling, and zeal thus capture both personal and literary change. They help us understand the early development of her own poetic identity, as well as the beginnings of the new literary movement in which she would spend her adult career, and which her writing would shape in fundamental ways. Enthusiasm may have been 


\section{Rachael Isom | Elizabeth Barrett's Juvenile Poetics}

Barrett's link to Romanticism, but it also informs the inspired yet vocational female poet she would embody for the Victorian age.

\section{Notes}

${ }^{1}$ Research for this article has been supported by fellowships from the Armstrong Browning Library, the New York Public Library, and the Huntington Library. I am especially grateful to Jennifer Borderud and Melvin Schuetz of the ABL, and to Lyndsi Barnes and Carolyn Vega of the NYPL's Henry W. and Albert A. Berg Collection of English and American Literature. I also thank Beverly Taylor, Jeanne Moskal, Laurie Langbauer, and the anonymous reviewer for the Journal of Juvenilia Studies for their helpful feedback.

2 Four years earlier, in "Lines on the Death of Lord Byron" (1824), Barrett described the "warm enthusiasms" that had "Glowed" in Byron's heart (lines17-18). The poem remained unpublished during her lifetime. For Romantic poetry and "transport," see Mee 54. Some examples include Canto 12 of Shelley's The Revolt of Islam, which begins, "The transport of a fierce and monstrous gladness / Spread through the multitudinous streets” (II.1-2); Byron's Childe Harold's Pilgrimage, Canto 4, CXIX.4; and Byron's Don Juan, Canto 1, stanzas 88-89. The word also appears several times in Wordsworth's Prelude, often referring to youthful transport amidst scenes of nature (see II.376, 410; VIII.111; XI.150; XII.142; and XIII.109).

${ }^{3}$ For Barrett's early Byronism, see Stone and Taylor, introduction 12-14; Stabler 235-39; and Mermin 34. For her admiration of Wordsworth, see LaPorte, Victorian Poets 35; Cooper 37; Woolford 45-47; and K. Blake 388. For the influence of Romanticism in general on Barrett's formation as a poet, see Stabler 233-34, Knowles 137-39, and Stone 49.

${ }^{4}$ In 1750, Samuel Johnson defined enthusiasm as "a vain confidence of divine favour or communication" (Oxford English Dictionary, s.v. "enthusiasm,” accessed 9 Jan. 2017). For enthusiasm's historical links to Methodism and other Dissenting faith traditions, see Anderson 35-37, 49-50, 53; Lloyd 19; Mack 18; Cragwall 6; and Mee 14, 16, 64, 71, 214-215. For women and religious zeal, see Anderson 77, Hempton 180-82, Mack 21, and Lloyd 36.

5 This claim elaborates on a Romantic-era cultural phenomenon that Alan Richardson has termed "the colonization of the feminine" (13-25).

6 As the anonymous "Editor" points out, the two essays reproduced in this article were once privately held, but the manuscript of "Glimpses into My Own Life and Literary Character" is now at the Huntington Library. Both essays have been published in BC 1:347-56. "Glimpses" has lately been reproduced in Elizabeth Barrett Browning, ed. Billington and Davis. For Barrett and Evangelicalism, see LaPorte, Victorian Poets 23-24, 45.

${ }^{7}$ Full-text searches of Elizabeth Barrett Browning's later published verse reveal no incidences of "enthusiasm" or any of its forms. The most salient example is her nine-book epic, Aurora Leigh, which spends pages theorizing and depicting feminine poetics but never once uses the term.

${ }^{8}$ See also Avery, "Constructing" 27; and Cooper 12-13.

${ }^{9}$ For echoes of Shakespeare in EBB's poetry, see Marshall 467-86. For the Victorians' obsession with Shakespeare, see LaPorte, "Bard" 609-628, esp. 609-610. For EBB and Milton, see Gray 37-41, 168-70; Brown 723-40; and Woolford 51-52.

10 The Book of Common Prayer for 1792, the same year as Gilpin's book, frequently uses "delight" or "great delight" (475, 485, 487 497, 507). See also Hymns 78 and 309 in The Congregational Hymn Book. In citing this particular hymnbook, I follow Dieleman 38. The word "delight" appears 24 times in the King James Version of the Psalms.

11 This portion of "My Own Character" is not included in Kelley and Hudson, so I have quoted from the text as rendered in "Two Autobiographical Essays," which reproduces the transcript made by Barrett's mother, Mary Moulton-Barrett (ABL Ms. D1326).

${ }^{12}$ As Dieleman has shown in detail, Barrett later abandoned this position and maintained a Congregationalist identity. See, for example, her letter to William Merry on 2 November 1843: "I 


\section{JJS July 2019}

am not myself a member of the Church of England" (rpt. in Barrett, Religious Opinions 13). Barrett's ecumenism shows in her private defense of Methodist practice in the 1830s (see Diary 8, 10), and in her embrace of Swedenborgianism in the 1840s (see LaPorte, Victorian Poets 48; Stone and Taylor 38).

${ }^{13}$ See, for instance, Samuel Taylor Coleridge's use of "fancy" to describe undesirable enthusiasm (Mee 12, 176).

${ }^{14}$ For summaries of the Queen Caroline controversy, see BC 1:98n1; Browning, Works 5:341-42; and Gardner 157-217. Barrett was invested in Caroline's trial. She mentioned it in letters and even dramatised the Queen's departure from England in the unfinished Princess Caroline of Brunswick [1820] (see Works 5:341-47; Avery, Lives 2; Mermin 27; and "Two" 134n12).

15 As Scheinberg points out, Barrett's study of Hebrew did not begin until 1832, and several poems from her later 1830s publications contain untranslated Hebrew words "coincident with very important statements about religious or literary authority” (70-76, qtd. from 76). Most of Diary's religious disquisitions engage with contemporary Calvinism versus Arminianism or contemplate a more ecumenical Christianity in Britain. See also Religious Opinions.

16 These phrases have been translated by Diary editors Kelley and Hudson.

${ }^{17}$ These thoughts cohere with Barrett's earlier sense of Shelley's poetry as "too immaterial for our sympathies to enclasp it firmly"; she writes, "it reverses the lot of human plants: its roots are in the air, not earth!" (Diary 103). They also bring to mind Maria Jane Jewsbury's description of Shelley in her review of The Wandering Jew, published earlier that same year: "a winged head, unable to walk the earth, but at home when soaring through the sky" (457). For Barrett and Shelley, see LaPorte, Victorian Poets 23, 26, 32, 47; and Stabler 235.

${ }^{18}$ For Barrett and the Romantic revival of poet as vates, see LaPorte, Victorian Poets 25.

${ }^{19}$ Later in Book II, EBB invokes "Enchanting Poesy," granting it a spellbinding or, in this case, inspiring power, similar to that of Mind itself (Essay II.940).

${ }^{20}$ In her copy of An Essay on Mind, Barrett's aunt Arabella Graham-Clarke noted that the comparison with Mont Blanc registered "a high degree of eminence even for Byron." She went on to remark (in true English fashion), "I wish the loftiest summit of the Alps had a more poetical name not a French one" (9; see also The Brownings: A Research Guide, entry C0028). Josiah Conder of The Eclectic Review also objected to the poem's "very affecte[d]" styling of Byron as an intellectual Mont Blanc (80). (The review has been attributed to Conder by Wellesley College in the British Periodicals Database.)

${ }^{21}$ In February 1829, another unidentified correspondent lauded Barrett as Essay's author in a much lengthier poem (BC 2:181-84). Some reviewers also guessed Barrett's authorship, though not until two years later (see The Imperial Magazine [May 1828]: 459-62; and The Gentleman's Magazine [December 1828]: 533). When Essay first appeared in 1826, some speculated that it was the work of a young woman (see The Literary Gazette [July 15, 1826]: 436; and La Belle Assemblée [August 1826]: 85). These reviews were located via The Browning Database at the ABL.

22 In Book I of An Essay on Mind, Barrett writes: "The fancy kindles, and the pages glow; / When, one bright hour, and startling transport past, / The musing soul must turn — to sigh at last" (lines 279-81). In Book II, she describes an "internal transport, past the knowing!" that occurs when the youthful soul is "glowing" over a page of poetry (lines 836-37). 


\section{Rachael Isom | Elizabeth Barrett's Juvenile Poetics}

\section{WORKS CiTED}

Works or locations frequently cited have been identified by the following abbreviations:

ABL Armstrong Browning Library, Baylor University, Waco, Texas.

$B C \quad$ Browning, Robert, Elizabeth Barrett Browning, and others. The Brownings' Correspondence. Edited by Philip Kelley and Ronald Hudston, Wedgestone Press, 1984. 25 vols.

Essay Barrett, Elizabeth. An Essay on Mind. Works, vol. 4, pp. 82-131.

Works Browning, Elizabeth Barrett. The Works of Elizabeth Barrett. General editor Sandra Donaldson, Pickering \& Chatto, 2010. 5 vols.

Anderson, Misty G. Imagining Methodism in Eighteenth-Century Britain: Enthusiasm, Belief \& the Borders of the Self. Johns Hopkins UP, 2012.

Avery, Simon. "Audacious Beginnings: Elizabeth Barrett's Early Writings." Elizabeth Barrett Browning, edited by Avery and Rebecca Stott, Pearson, 2003, pp. 46-64.

_. "Constructing the Poet Laureate of Hope End." Elizabeth Barrett Browning, edited by Avery and Rebecca Stott, Pearson, 2003, pp. 23-42.

Avery, Simon, editor. Lives of Victorian Literary Figures II: The Brownings, the Brontës, and the Rossettis, by Their Contemporaries. Vol. 1, Pickering \& Chatto, 2004.

Barrett, Elizabeth. The Diary of E. B. B.: The Unpublished Diary of Elizabeth Barrett, 1831-1832. Edited by Philip Kelley and Ronald Hudson. Ohio UP, 1969.

—. "Glimpses into My Own Life and Literary Character." Kelley and Hudson, pp. 348-56.

—. "Lines on the Death of Lord Byron." Works, vol. 5, pp. 442-43.

- "My Character and Bro's Compared." Kelley and Hudson, pp. 357-58.

"My Own Character." Kelley and Hudson, pp. 347-48.

- Preface to An Essay on Mind, with Other Poems. Works, vol. 4, pp. 77-81

- "Two Autobiographical Essays by Elizabeth Barrett." Browning Institute Studies, vol. 2, 1974, pp. 119-34.

—. "A Vision An Allegory." The Works of Elizabeth Barrett Browning, Works, vol. 5, pp. 259-60.

Beer, John. William Blake: A Literary Life. Palgrave Macmillan, 2005.

Blake, Kathleen. "Elizabeth Barrett Browning and Wordsworth: The Romantic Poet as Woman." Victorian Poetry, vol. 24, no. 4, 1986, pp. 387-98.

The Book of Common Prayer, and Administration of the Sacrament, According to the Use of the Church of England. London: T. Davison, 1792.

Brown, Sarah Annes. "Paradise Lost and Aurora Leigh." SEL, vol. 37, no. 4, 1997, pp. $723-40$.

Browning, E. B. Ms. D0247. An Essay on Mind. Browning Collections, ABL. . Ms. D1326. My Own Character [1818]. Transcript by Mary Moulton-Barrett. Browning Collections, ABL.

Browning, Elizabeth Barrett. Aurora Leigh. Edited by Sandra Donaldson. Works, vol. 3. 


\section{JJS July 2019}

- Elizabeth Barrett Browning. Edited by Josie Billington and Philip Davis, Oxford UP, 2014.

- The Religious Opinions of Elizabeth Barrett Browning as Expressed in Three Letters Addressed to Wm. Merry, Esq. J.P. Edited by W. Robertson Nicoll, London: privately printed, 1896.

Byron, George Gordon. Childe Harold's Pilgrimage. Lord Byron: The Complete Poetical Works, edited by Jerome J. McGann, vol. 2, Oxford UP, 1980.

- Don Juan. Lord Byron: The Complete Poetical Works, edited by Jerome J. McGann, vol. 5, Oxford UP, 1992.

The Congregational Hymn Book: A Supplement to Dr. Watts's Psalms and Hymns, compiled by The Congregational Union of England and Wales. London: Jackson \& Walford, 1836.

[Conder, Josiah.] "Art. X. An Essay on Mind, with Other Poems." The Eclectic Review, vol. 26, July 1826, pp. 78-82.

Cooper, Helen. Elizabeth Barrett Browning, Woman \& Artist. U of North Carolina P, 1988.

Cragwall, Jasper. Lake Methodism: Polite Literature and Popular Religion in England, 1780-1830. Ohio State UP, 2013.

Dieleman, Karen. Religious Imaginaries: The Liturgical and Poetic Practices of Elizabeth Barrett Browning, Christina Rossetti, and Adelaide Proctor. Ohio UP, 2012.

"Essay on Mind." La Belle Assemblée, or Bell's Court and Fashionable Magazine, Aug. 1826, p. 85.

“An Essay on Mind, with Other Poems." The Gentleman's Magazine, Dec. 1828, p. 533.

"Essay on Mind, with other Poems." The Literary Gazette, no. 495, 15 July 1826, pp. 436.

Forster, Margaret. Elizabeth Barrett Browning: A Biography. Chatto \& Windus, 1988.

Gardner, John. Poetry and Popular Protest: Peterloo, Cato Street, and the Queen Caroline Controversy. Palgrave Macmillan, 2011.

Gilchrist, Alexander. Life of William Blake ... A New and Enlarged Edition. London: Macmillan,1880. 2 vols.

Gilpin, William. "Essay II.” Three Essays: On Picturesque Beauty; On Picturesque Travel; and On Sketching Landscape. London: R. Blamire, 1792.

Graham Clarke, Arabella. Annotations to An Essay on Mind, with Other Poems. London: James Duncan, 1826. ABL. Holograph.

Gray, Erik. Milton and the Victorians. Cornell UP, 2009.

Hempton, David Methodism: Empire of the Spirit. New Haven: Yale UP, 2005.

[Jewsbury, Maria Jane.] "Shelley's 'Wandering Jew." The Athenaeum, no. 194,16 July 1831, pp. 456-57.

Juster, Susan. Disorderly Women: Sexual Politics \& Evangelicalism in Revolutionary New England. Cornell UP, 1994.

Knowles, Claire. Sensibility and Female Poetic Tradition, 1780-1960: The Legacy of Charlotte Smith. Ashgate, 2009.

LaPorte, Charles. "The Bard, the Bible, and the Shakespeare Question," ELH, vol. 74, 2007, pp. 609-628.

—. Victorian Poets and the Changing Bible. U of Virginia P, 2011. 


\section{Rachael Isom | Elizabeth Barrett's Juvenile Poetics}

Lloyd, Jennifer M. Women and the Shaping of British Methodism: Persistent Preachers, 1807-1907. Manchester UP, 2010.

Mack, Phyllis. Heart Religion in the British Enlightenment: Gender and Emotion in Early Methodism. Cambridge UP, 2008.

MacKay, Carol Hanbery. "Emerging Selves: The Autobiographical Impulse in Elizabeth Barrett Browning, Anne Thackeray Ritchie, and Annie Wood Besant." A History of English Autobiography, edited by Adam Smyth, Cambridge UP, 2006, pp. 207-220.

Marshall, Gail. "Elizabeth Barrett Browning and Shakespeare: Translating the Language of Intimacy." Victorian Poetry, vol. 44, no. 4, 2006, pp. 467-86.

Mee, Jon. Romanticism, Enthusiasm, and Regulation: Poetics and the Policing of Culture in the Romantic Period. Oxford UP, 2003.

Mermin, Dorothy. Elizabeth Barrett Browning: The Origins of a New Poetry. U of Chicago P, 1989.

"Review.-An Essay on Mind, with other Poems." The Imperial Magazine, vol. 10, no. 113, May 1828, pp. 459-61.

Richardson, Alan. "Romanticism and the Colonization of the Feminine." Romanticism and Feminism, edited by Anne K. Mellor, Indiana UP, 1988, pp. 1325.

Scheinberg, Cynthia. Women's Poetry and Religion in Victorian England: Jewish Identity and Christian Culture. Cambridge UP, 2002.

Shelley, Percy Bysshe. The Revolt of Islam. The Complete Poetry of Percy Bysshe Shelley, edited by Donald H. Reiman and Neil Fraistat, vol. 2, Johns Hopkins UP, 1999.

Stabler, Jane. "Romantic and Victorian Conversations: Elizabeth Barrett and Robert Browning in Dialogue with Byron and Shelley." Fellow Romantics: Male and Female British Writers, 1790-1835, edited by Beth Lau, Routledge, 2009, pp. 231-53.

Stone, Marjorie. Elizabeth Barrett Browning. St. Martin's Press, 1995.

Stone, Marjorie, and Beverly Taylor, editors. Elizabeth Barrett Browning: Selected Poems. By Elizabeth Barrtt Browning, introduction, headnotes, and annotations by Stone and Taylor, Broadview, 2009.

Unidentified Correspondent. "To Miss Barrett on Reading her Essay on Mind." Kelley and Hudson, pp. 231-32.

Woolford, John. "Elizabeth Barrett and the Wordsworthian Sublime." Essays in Criticism, vol. 45, no. 1, 1995, pp. 36-56.

Wordsworth, William. Lyrical Ballads, and Other Poems, 1797-1800. Edited by James Butler and Karen Green. Cornell UP, 1992.

- The Fourteen-Book Prelude. Edited by W. J. B. Owen. The Cornell Wordsworth, vol. 22, Cornell UP, 1985. 